\title{
Assessment of physiological potential of stored pea (Pisum sativum L.) seeds ${ }^{1}$
}

\author{
Fábio Mielezrski², Julio Marcos-Filho ${ }^{3 *}$
}

\begin{abstract}
Research on pea seed storage and the identification of efficient seed vigor tests for this species is still insufficient, especially for cultivars that produce wrinkled seeds used for consumption in natura. The objective of this study was to verify the accuracy of tests to assess the physiological potential of pea seed lots stored in different environments. Four seed lots of two cultivars, 'Telefone Alta' (indeterminate growth habit) and 'Itapuã' (determinate growth habit) were stored under different environmental conditions for 8 months: a) laboratory uncontrolled b) dry and cold chamber $\left(10{ }^{\circ} \mathrm{C}\right.$ and $\left.30 \% \mathrm{RH}\right)$, c) controlled environment $\left(20^{\circ} \mathrm{C}\right.$ and $\left.70 \% \mathrm{RH}\right)$. Seed vigor (accelerated aging, electrical conductivity, seedling length and seedling emergence) was evaluated initially and after four and eight months storage. Results showed that the use of seed lots of high initial physiological potential is fundamental for guaranteeing the desired performance of pea seeds during storage. Wrinkled pea seeds should be stored between harvest and sowing in an environment in which the sum of the relative humidity (\%) and temperature $\left({ }^{\circ} \mathrm{C}\right)$ does not exceed 70 . Physiological potential of pea seeds should be evaluated by at least two vigor tests; consideration to accelerated aging and electrical conductivity tests is recommended.
\end{abstract}

Index terms: Pisum sativum L., seed vigor, deterioration, storability.

\section{Determinação do potencial fisiológico de sementes armazenadas de ervilha}

\begin{abstract}
RESUMO - A pesquisa sobre avaliação do comportamento de sementes de ervilha durante o armazenamento e para identificação de testes eficientes para a determinação do vigor é relativamente escassa, especialmente quando se consideram cultivares de sementes rugosas produzidas para consumo de grãos verdes debulhados. Este trabalho teve como objetivo verificar a eficiência de testes para avaliação do potencial fisiológico de sementes de ervilha durante o armazenamento. Utilizaram-se quatro lotes de duas cultivares, 'Telefone Alta' e 'Itapuã 600', armazenados em três condições, durante oito meses: a) ambiente de laboratório; b) câmara seca $\left(20^{\circ} \mathrm{C}\right.$ e $\left.50 \% \mathrm{UR}\right)$; c) ambiente controlado $\left(20^{\circ} \mathrm{C}\right.$ e $\left.70 \% \mathrm{UR}\right)$. As avaliações da germinação, do vigor (envelhecimento acelerado, condutividade elétrica, comprimento e emergência de plântulas) e da sanidade foram efetuadas no início do armazenamento, aos quatro e aos oito meses. Verificou-se que a utilização de lotes com potencial fisiológico inicial elevado é fundamental para a conservação de sementes de ervilha durante o armazenamento. Sementes rugosas devem ser armazenadas, entre a colheita e a semeadura, em ambiente em que a soma da umidade relativa (\%) e temperatura do ar $\left({ }^{\circ} \mathrm{C}\right)$ não supere 70. A avaliação do potencial fisiológico de sementes de ervilha deve ser realizada com utilização de, pelo menos, dois testes de vigor, recomendando-se a inclusão do envelhecimento acelerado e da condutividade elétrica.
\end{abstract}

Termos para indexação: Pisum sativum L., vigor de sementes, deterioração, potencial de armazenamento.

\section{Introduction}

The pea (Pisum sativum L.), a species from the Middle East, was introduced in the South and later in Central Brazil, more specifically to the cerrado areas, demonstrating excellent adaptation, high productivities, relatively low disease attack and a favorable response to irrigation (Giordano, 1997).

\footnotetext{
${ }^{1}$ Submitted on 01/30/2012. Accepted for publication on 06/27/2012.

${ }^{2}$ Monsanto do Brasil, 18730-000 - Itaí, SP, Brasil.

${ }^{3}$ Departamento de Produção Vegetal, USP/ESALQ, Caixa Postal 9, 13418-900 - Piracicaba, SP, Brasil.
}

Peas are commercialized in Brazil as dry grains for canning or freezing, and edible pods and threshed green peas for consumption in natura (Nascimento et al., 2007). Each of these segments needs cultivars with specific characteristics, including variations in seed size, color and chemical composition. The seeds destined for threshed green pea production for consumption in natura have higher sugar

*Corresponding author <juliomarcos.1@usp.br> 
than starch content and they are wrinkled after drying; in smooth seed cultivars, the starch content is higher than that of sugars. The differences in chemical composition and seed shape are associated with physiological potential and health, and wrinkled seeds need more careful handling before and after harvest to avoid significant decreases in vigor. (Nascimento and Cícero, 1991a,b).

Various factors directly influence seed physiological potential, including storage conditions, which are fundamental for maintain viability and vigor. This is significantly affected by initial seed physiological quality, seed water content, relative humidity and temperature, action of microorganisms and insects, and the storage period (Carvalho and Nakagawa, 2000). It is well known that seed deterioration is faster and intense in tropical and subtropical regions due to the unfavorable pre- and post-harvest weather conditions (Baudet, 2003).

Delouche et al. (1973) have defined favorable combinations of temperature $\left({ }^{\circ} \mathrm{C}\right)$ and relative humidity (\%) for storing seeds of important crops in an uncontrolled environment. Thus, for a maximum storage period of 8 months, the sum of the relative humidity $(\%)$ and temperature $\left({ }^{\circ} \mathrm{C}\right)$ should not be higher than 80 or higher than 65 to 70 for a 12 to 18 month storage period. However, in artificial environments and for prolonged periods ( 5 to 15 years), this total should be less than 45 to 55 .

Under the tropical conditions in Brazil, the period between pea seed harvesting and the next sowing time usually coincides with high temperature and relative humidity, which adversely affect seed viability of this "winter crop". Abdalla and Roberts (1969), when evaluating stored pea seeds performance, found that increases in temperature and relative humidity adversely affected seed viability. Caliari and Marcos-Filho (1990), studying the efficiency of vigor tests for pea seeds in an uncontrolled environment for 8 months, observed that even minor variations in the environment may cause a rapid decrease in physiological potential.

On the other hand, according to Doijode (2001), seed viability and vigor of peas are rapidly reduced when stored at less favorable temperatures, mainly for seed lots of higher water content (near to $13 \%$ ), which also favored the action of microorganisms. At the same time, Vertucci et al. (1994) emphasized that the effects of water content and temperature on pea seeds during storage cannot be considered as independent.

However, although this information is very important, relatively few data on the physiological potential of pea seeds during storage are documented in the literature. Therefore, considering the economic importance of this crop and its uses in human and animal nutrition, more studies are needed to clarify the relationship between physiological potential and pea seed lots performance before and after storage, in order to produce basic information to establish guidelines for the proper management and to assure a uniform stand after sowing.

Although the literature has described frequent differences between laboratory results and seedling emergence in the field, especially under less favorable environmental conditions, the amount of information on procedures for determining the vigor of pea seeds is still insufficient. Tests used on pea seeds include: traditional accelerated aging (Menezes and Nascimento, 1988; Caliari and Marcos-Filho, 1990; Nascimento and Cicero, 1991; Hampton et al., 2004) and saturated salt accelerated aging (Nascimento et al., 2007), electrical conductivity (Bradnock and Mathews, 1970; Bustamante et al., 1984; Caliari and Marcos-Filho, 1990; Nascimento and Cicero, 1991b; Powell et al., 1997), controlled deterioration (Bustamante et al., 1984; Powell et al., 1997; Siddique and Wright, 2004), seedling vigor classification (Caliari e Marcos-Filho, 1990) and percentage or speed of seedling emergence (Bustamante et al., 1984; Caliari and Marcos-Filho, 1990; Nascimento and Cicero, 1991b). These tests have provided consistent results but it is important to identify procedures allowing the evaluation of different characteristics which determine vigor; also, since results are influenced by the genotype, the efficiency of each test also depends on the cultivar being evaluated.

As a consequence, it is important to focus on research directed to cultivars producing wrinkled seeds, which are more problematic regarding physiological potential. The objectives of this study were to evaluate the behavior of pea seed lots during storage under different conditions and verify the efficiency of different procedures for vigor testing.

\section{Material and Methods}

The study was performed at the Seed Analysis Laboratory and the Experimental Plot of the Crop Science Department of ESALQ (Escola Superior de Agricultura "Luiz de Queiroz"), University of São Paulo-USP, Piracicaba/SP. Two pea cultivars were used, Telefone Alta (Alderman) and Itapuã 600 , both producing wrinkled seeds for the commercialization in natura of threshed green peas. Seeds of four lots of each cultivar produced by ISLA Sementes Ltda. were treated with Thiram (200 g a.i./ $100 \mathrm{~kg}$ of seeds).

Seed lot germination was higher than the minimum value established for pea seed commercialization $(80 \%)$, but showed differences in vigor. After reception, the lots were placed in cotton mesh bags, evaluated for initial physiological potential and stored in different environments for eight months (December 2008 to August 2009) as follows: a) laboratory, daily registration of temperature and relative humidity (Lab); b) dry chamber, at $20^{\circ} \mathrm{C}$ and $50 \% \mathrm{RH}$ (Dry); c) controlled environment, at $20^{\circ} \mathrm{C}$ and $70 \% \mathrm{RH}$ (Controlled). 
This controlled environment was established using an $\mathrm{NaCl}$ solution in a plastic box ( $30 \times 16 \times 9 \mathrm{~cm})$, positioned inside another plastic box with a $23 \mathrm{~L}$ capacity $(52 \times 35 \times 14 \mathrm{~cm})$; in each "external" box, seed samples were kept in cotton bags, representing each lot of each cultivar . One kilogram of seeds from each lot and cultivar was placed within each external plastic box and a solution $(2.5 \mathrm{~L}$ of water $+788 \mathrm{~g}$ of $\mathrm{NaCl}$ ) was used to keep a controlled environment with the RH close to $70 \%$ (Sun, 2002). Therefore, each "external" box, kept sealed throughout the experiment, contained four $1 \mathrm{~kg}$ bags of each cultivar, representing the statistical replications, which totaled eight stored boxes representing the controlled environment. The relative humidity inside each box was monitored with a hygrometer.

Periodically, at intervals of approximately 60 days, the $\mathrm{NaCl}$ solution was changed in all the internal boxes to guarantee the pre-established environmental conditions. During the storage period, the boxes representing the controlled environment were kept in a dry chamber $\left(20^{\circ} \mathrm{C}\right.$ and $50 \% \mathrm{RH}$ ) so that the seeds would not show significant variations in water content, which could happen if there were changes in the environmental temperature. The mean monthly temperature and relative humidity during storage in the laboratory environment (LAB), measured with a thermohygrograph, are listed in Table 1.

Table 1. Mean monthly temperatures $\left({ }^{\circ} \mathrm{C}\right)$ and relative humidities (\%) of the uncontrolled environment during eight months of seed storage.

\begin{tabular}{lcc}
\hline \multicolumn{1}{c}{ Month/Year } & $\begin{array}{c}\text { Mean Temperature } \\
\left({ }^{\circ} \mathrm{C}\right)\end{array}$ & $\begin{array}{c}\text { Relative Humidity } \\
(\%)\end{array}$ \\
\hline December/2008 & 24.7 & 74.7 \\
January/2009 & 24.8 & 81.0 \\
February/2009 & 25.3 & 82.0 \\
March/2009 & 26.2 & 75.0 \\
April/2009 & 23.8 & 71.7 \\
May/2009 & 21.8 & 74.7 \\
June/2009 & 16.1 & 79.5 \\
July/2009 & 17.4 & 83.4 \\
August/2009 & 18.3 & 74.7 \\
\hline
\end{tabular}

Determinations of the seed water content, physiological potential and health were performed at the beginning of storage and at two month intervals over eight months; however, only the results at the beginning of storage (December 2008) and after four (April 2009) and eight months (August 2009), as they were sufficient to attend the objectives for this study.

Since the seeds were kept under different storage conditions and showed different water contents, samples from each environment were placed in a cold and dry chamber $\left(10{ }^{\circ} \mathrm{C}\right.$ and $30 \% \mathrm{RH}$ ) for five days before the start of each period to evaluate germination and vigor. Uniformity of seed water content is important for standardization of procedures.

Seed water content: determined by the oven method at 105 $\pm 3{ }^{\circ} \mathrm{C}$ for 24 hours, according to the Rules for Seed Testing (Brasil, 2009), before each test and after both accelerated aging procedures. Results were expressed as a percentage (wet basis).

Germination: conducted with four replications of 50 seeds each, distributed in paper towel rolls moistened with an amount of water 2.5 times the substrate weight at $20^{\circ} \mathrm{C}$. The test was evaluated five and eight days after sowing, according to the criteria described in the Rules for Seed Testing (Brasil, 2009). The percentage germination represented the mean of the four replications for each lot and cultivar.

Electrical conductivity: four replications of 25 seeds previously weighed $(0.01 \mathrm{~g})$ were placed in plastic cups containing $75 \mathrm{~mL}$ of distilled water and kept in a germinator at $20{ }^{\circ} \mathrm{C}$ for 24 hours. After this period, the conductivity was measured using a digital conductivity meter and the results expressed in $\mu \mathrm{mho} . \mathrm{cm}^{-1} \cdot \mathrm{g}^{-1}$ of seeds (Vieira and Krzyzanowski, 1999), for each lot and cultivar.

Accelerated aging: at $41{ }^{\circ} \mathrm{C}$ for 48 hours in an aging chamber, according to Caliari and Marcos-Filho (1990). After aging, seed samples were set to germinate as described previously and the percentage of normal seedlings was recorded five days after sowing for each lot and cultivar.

Seedling length: four replications of 20 seeds each per lot were used. Paper towel rolls were moistened with a quantity of water 2.5 times the substrate weight and kept in a germinator at $20^{\circ} \mathrm{C}$ for 5 days; the length of the normal seedlings was measured in centimeters using a graduated ruler (Nakagawa, 1999). The results represented the division of the sum of the lengths by the total number of normal seedlings of each replication, for each lot and cultivar.

Seedling emergence: evaluated in the field with four replicates of 100 seeds per lot, distributing 25 seeds per linear meter at $0.05 \mathrm{~m}$ depth with $0.50 \mathrm{~m}$ between rows. Counts were performed at 15 days after sowing and the results were expressed as mean percentages for each lot and cultivar (Caliari and Marcos-Filho, 1990).

Health: the filter paper method was used without freezing (Lucca Filho, 1987). Four replications of 50 seeds each per treatment were distributed in Petri dishes containing four sheets of filter paper previously moistened with distilled water. The plates were placed in chambers for incubation at $20{ }^{\circ} \mathrm{C}$, with 12 hours fluorescent white light, and microorganisms were evaluated after 10 days. Results were expressed as a mean percentage of infected seeds per lot and cultivar. 
Statistical analysis: for the laboratory tests, except for the evaluation of seed water content, the statistical analysis was performed on a completely random factorial design (lots $\mathrm{x}$ environments) and the means compared with the Tukey test $(\mathrm{p} \leq 0.05)$.

\section{Results and Discussion}

The three storage ambients (laboratory, dry chamber and controlled) had different relative humidities and temperatures, leading to the hypothesis that the seed lots from the two cultivars in this study could show variations in the speed and intensity of deterioration, sufficient for evaluating the sensibility of tests performed to identify differences in physiological potential. Therefore, based on Delouche et al. (1973), the dry chamber $\left(\mathrm{T}{ }^{\circ} \mathrm{C}+\right.$ R.H.\% $\left.=70\right)$ would be more suitable for conserving seeds than the controlled $\left(\mathrm{T}^{\circ} \mathrm{C}+\right.$ R.H.\% $\%$ 90) and the laboratory $\left(\mathrm{T}^{\circ} \mathrm{C}+\right.$ R.H.\% $=95.5$ to 107.3 , see Table 1) environments.

The germination of seed lots of 'Telefone Alta' and 'Itapuã 600' was similar to that established for the commercialization of pea seeds $(\geq 80 \%)$, with the exception of lot 7 from 'Itapuã 600'. This situation is desirable in research on seed vigor because it does not make sense to evaluate seed lots which do not attain the minimum standards for commercialization, unless for an academical approach. In fact, if or when the germination test conducted under the best environmental conditions could should be able to detect lot differences, there is no reason to spend additional time and efforts to determine seed vigor.

There was no significant difference between the initial germination $(80 \%$ to $90 \%)$ of 'Telefone Alta' seed lots (Table 2). The results of the other vigor tests performed here demonstrated the superiority in vigor of lot 4 , accompanied by lot 1 the accelerated aging and seedling emergence tests and the lower performance of lots 2 and 3 (Table 2). Identification of the initial physiological potential is fundamental for successful storage and this is well documented in the literature, showing the advantages of the vigorous seed lots.

Table 2. Germination (G), accelerated aging (AA), electrical conductivity (EC), seedling length (SL), seedling emergence (SE) and water content of four lots of pea seeds, 'Telefone Alta', at the beginning of storage.

\begin{tabular}{|c|c|c|c|c|c|c|}
\hline Lots & G (\%) & AA (\%) & 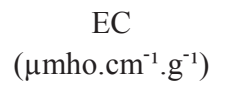 & $\begin{array}{c}\text { SL } \\
\left(\mathrm{cm}^{\text {seedling }}{ }^{-1}\right)\end{array}$ & SE $(\%)$ & Water content $(\%)$ \\
\hline 1 & $90 \mathrm{a}^{*}$ & $37 \mathrm{~b}$ & $104.5 b$ & $9.2 \mathrm{ab}$ & $77 \mathrm{a}$ & 9.0 \\
\hline 2 & $81 \mathrm{a}$ & $27 \mathrm{c}$ & $115.5 \mathrm{~b}$ & $8.6 \mathrm{~b}$ & $60 \mathrm{~b}$ & 10.7 \\
\hline 3 & $80 \mathrm{a}$ & $19 \mathrm{c}$ & $121.5 \mathrm{~b}$ & $8.1 \mathrm{~b}$ & $55 \mathrm{~b}$ & 9.1 \\
\hline 4 & $89 \mathrm{a}$ & $60 \mathrm{a}$ & $51.3 \mathrm{a}$ & $10.7 \mathrm{a}$ & $85 \mathrm{a}$ & 11.7 \\
\hline $\mathrm{CV}(\%)$ & 7.0 & 12.1 & 16.1 & 9.2 & 7.0 & -- \\
\hline
\end{tabular}

*Small letters: comparisons in each column (Tukey test, $\mathrm{p} \leq 0.05$ ).

The seed health test showed a reduced occurrence of Penicillium and Rhizopus (0 to $5 \%$ ) and $11 \%$ to $22 \%$ infection by Aspergillus, which was higher in seeds from lots 2 and $3(17 \%$ and $22 \%$, respectively) and lower in seeds from lot $4(11 \%)$. The incidence of these microorganisms may be associated with adverse pre-harvest environmental factors since this study involved recently-harvested seeds with initial water content between $9.0 \%$ and $11.7 \%$ (Table 2). It is known that wrinkled pea seeds cultivars for consumption in natura are more prone to deterioration fungus attack (Nascimento and Cicero, 1991 a, b).

In general, after four months storage, the performance of seed lots stored in the dry chamber was superior in germination, accelerated aging and seedling emergence tests; however, significant differences were not observed in some lots although numerical values should be higher (Table 3). Again, the vigor of lots 2 and 3 was lower, confirming initial observations (Table 2); only the seedling length test did not detect any differences among lots or environments at this evaluation period.
Lots 2 and 3 had the greatest incidence of Aspergillus attack in all environments, reaching values of $57 \%$ and $51 \%$, respectively, for laboratory stored seeds. The germination of those lots stored in the laboratory and controlled environments was lower than the minimum established for commercialization. Only lots 1 and 4 , maintained in the dry chamber, and lot 4 in the laboratory, kept their relatively high germination. Generally, all the tests, mainly accelerated aging and electrical conductivity, showed reduction in physiological potential for the four lots compared to the initial period, confirming the initial hypothesis regarding the possible better conservation of seeds in the dry chamber.

After eight months, these trends were maintained, that is, the lower performance of lots 2 and 3 (principally the latter), and the superiority of lots 1 and 4 and of storage in the dry chamber (Table 4). The possible differences in germination and/or vigor between seed lots stored in the laboratory and controlled environments were not consistent; consequently both were considered less favorable for seed storage. 
Table 3. Germination (G), accelerated aging (AA), electrical conductivity (EC), seedling length (SL), seedling emergence (SE) of four lots of 'Telefone Alta' pea seeds, after four months of storage in the laboratory (Lab), dry chamber (Dry) and controlled environment (Controlled).

\begin{tabular}{|c|c|c|c|c|}
\hline \multirow{2}{*}{ Tests } & \multirow{2}{*}{ Lots } & \multicolumn{3}{|c|}{ Treatments } \\
\hline & & Lab & Dry & Controlled \\
\hline \multirow{5}{*}{$\mathrm{G}(\%)$} & 1 & $71 \mathrm{Bb}^{*}$ & $82 \mathrm{Aa}$ & $78 \mathrm{Aab}$ \\
\hline & 2 & $54 \mathrm{Cc}$ & $70 \mathrm{Bab}$ & $68 \mathrm{ABb}$ \\
\hline & 3 & $47 \mathrm{Cb}$ & $65 \mathrm{Ba}$ & $60 \mathrm{Ba}$ \\
\hline & 4 & $86 \mathrm{Aab}$ & $90 \mathrm{Aa}$ & $79 \mathrm{ABb}$ \\
\hline & CV (\%) & & 8.0 & \\
\hline \multirow{5}{*}{ AA $(\%)$} & 1 & $04 \mathrm{ABb}$ & $14 \mathrm{Ba}$ & $11 \mathrm{Aa}$ \\
\hline & 2 & $01 \mathrm{Bb}$ & $06 \mathrm{Ca}$ & $05 \mathrm{Bab}$ \\
\hline & 3 & $06 \mathrm{Ab}$ & $07 \mathrm{Bb}$ & $07 \mathrm{Bb}$ \\
\hline & 4 & $09 \mathrm{Ab}$ & $24 \mathrm{Aa}$ & $12 \mathrm{Ab}$ \\
\hline & CV (\%) & & 22.3 & \\
\hline \multirow{5}{*}{$\begin{array}{c}\text { EC } \\
\left(\mu \mathrm{mho} . \mathrm{cm}^{-1} \cdot \mathrm{g}^{-1}\right)\end{array}$} & 1 & $156.9 \mathrm{Aa}$ & $162.0 \mathrm{Ba}$ & $145.9 \mathrm{Aa}$ \\
\hline & 2 & $247.9 \mathrm{Bb}$ & $196.5 \mathrm{Ba}$ & $167.0 \mathrm{Aa}$ \\
\hline & 3 & $246.9 \mathrm{Ba}$ & $175.9 \mathrm{Ba}$ & $172.2 \mathrm{Aa}$ \\
\hline & 4 & $136.8 \mathrm{Aab}$ & $118.6 \mathrm{Aa}$ & $163.9 \mathrm{Ab}$ \\
\hline & CV (\%) & & 11.5 & \\
\hline \multirow{5}{*}{ SL (cm.seedling $\left.{ }^{-1}\right)$} & 1 & $9.3 \mathrm{Aa}$ & $10.7 \mathrm{Aa}$ & $10.5 \mathrm{Aa}$ \\
\hline & 2 & $9.5 \mathrm{Aa}$ & $10.1 \mathrm{Aa}$ & $10.0 \mathrm{Aa}$ \\
\hline & 3 & $9.0 \mathrm{Aa}$ & $10.2 \mathrm{Aa}$ & $9.9 \mathrm{Aa}$ \\
\hline & 4 & $10.9 \mathrm{Aa}$ & $11.0 \mathrm{Aa}$ & $11.0 \mathrm{Aa}$ \\
\hline & CV (\%) & & 10.7 & \\
\hline \multirow{5}{*}{$\mathrm{SE}(\%)$} & 1 & $57 \mathrm{Ab}$ & $74 \mathrm{Aa}$ & $69 \mathrm{Ab}$ \\
\hline & 2 & $35 \mathrm{Bb}$ & $63 \mathrm{Ba}$ & $63 \mathrm{Aa}$ \\
\hline & 3 & $38 \mathrm{Bb}$ & $50 \mathrm{Ca}$ & $52 \mathrm{Ba}$ \\
\hline & 4 & $56 \mathrm{Ab}$ & $75 \mathrm{Aa}$ & $41 \mathrm{Cc}$ \\
\hline & CV (\%) & & 8.2 & \\
\hline
\end{tabular}

*Capital letters: comparisons in each column; small letters: comparisons in each row (Tukey test, $\mathrm{p} \leq 0.05$ ).

At the same time, the occurrence of Aspergillus increased, even when the seeds were treated with Thiram, confirming observations of Nascimento and Cicero (1991a) regarding the lower efficiency of this product for controlling storage fungi. The lower incidence of Penicillium was not surprising since this fungus develops mainly when the relative humidity is above $85 \%$ (Christensen, 1972), which did not occur in any of the environments where the seeds were stored.

There was a significant decrease in the physiological potential of the four lots stored in the three ambients after eight months, but it was less evident for lots 1and 4 (the most vigorous) kept in dry chamber (Table 4). This shows not only the influence of the initial physiological potential and the environmental conditions on seed conservation, but also the trend for wrinkled seeds to deteriorate and their association with the occurrence of Aspergillus. These results confirmed those from Caliari and Marcos-Filho (1990) and Nascimento and Cicero (1991a,b).

As observed for lots of the Telefone Alta cultivar, seeds of 'Itapuã 600 ', with the exception of lot 7, also showed a high initial physiological potential (Table 5). The initial occurrence of Penicillium and Rhizopus may be considered insignificant (levels of 0 to $2 \%$, depending on the lot) and the occurrence of Aspergillus was less pronounced than that observed in the 'Telefone Alta' seeds, not reaching 10\%.

At the beginning of the study, the significantly lower germination of the seeds from lot 7 was evident, as well as the lower vigor of lots 6 and 7 (in all the tests) and the better performance of lots 5 and 8 (Table 5). These results were repeated at four and eight months (Tables 6 and 7 , respectively), although one or other test may have shown occasional differences between lots 5 and 8 and lots 6 and 7. There was an increase in the levels of Aspergillus during storage, especially in lots 6 and 7, reaching 38\% and $55 \%$, respectively, for seeds stored for eight months in the laboratory. In the other treatments, values were generally lower than $10 \%$, indicating that probably the lots of 'Itapuã 600 ' were produced under more favorable climatic conditions during maturation. Once again, the levels of Aspergillus were directly associated with seed physiological potential. 
Table 4. Germination (G), accelerated aging (AA), electrical conductivity (EC), seedling length (SL), seedling emergence (SE) of four lots of 'Telefone Alta' pea seeds, after eight months of storage in the laboratory (Lab), dry chamber (Dry) and controlled environment (Controlled).

\begin{tabular}{|c|c|c|c|c|}
\hline \multirow{2}{*}{ Tests } & \multirow{2}{*}{ Lots } & \multicolumn{3}{|c|}{ Treatments } \\
\hline & & $\mathrm{Lab}$ & Dry & Controlled \\
\hline \multirow{5}{*}{$\mathrm{G}(\%)$} & 1 & $63 \mathrm{Bb}^{*}$ & $78 \mathrm{Aa}$ & $59 \mathrm{Ab}$ \\
\hline & 2 & $54 \mathrm{Ba}$ & $63 \mathrm{Ba}$ & $54 \mathrm{Aa}$ \\
\hline & 3 & $38 \mathrm{Cb}$ & $63 \mathrm{Ba}$ & $37 \mathrm{Bb}$ \\
\hline & 4 & $83 \mathrm{Aa}$ & $87 \mathrm{Aa}$ & $67 \mathrm{Ab}$ \\
\hline & CV (\%) & & 11.4 & \\
\hline \multirow{5}{*}{ AA (\%) } & 1 & $05 \mathrm{ABb}$ & $08 \mathrm{ABb}$ & $02 \mathrm{Ab}$ \\
\hline & 2 & $01 \mathrm{Bb}$ & $14 \mathrm{Ba}$ & $05 \mathrm{Ab}$ \\
\hline & 3 & $02 \mathrm{Bb}$ & $12 \mathrm{Ba}$ & $01 \mathrm{Ab}$ \\
\hline & 4 & $25 \mathrm{Ab}$ & $33 \mathrm{Aa}$ & $04 \mathrm{Ac}$ \\
\hline & CV (\%) & & 29.1 & \\
\hline \multirow{5}{*}{$\begin{array}{c}\text { EC } \\
\left(\mu \mathrm{mho} . \mathrm{cm}^{-1} \cdot \mathrm{g}^{-1}\right)\end{array}$} & 1 & $170.4 \mathrm{ABb}$ & $146.8 \mathrm{Aa}$ & $181.6 \mathrm{Ab}$ \\
\hline & 2 & $216.8 \mathrm{Bc}$ & $176.2 \mathrm{ABa}$ & $202.0 \mathrm{ABb}$ \\
\hline & 3 & $235.4 \mathrm{BCb}$ & $210.1 \mathrm{Ba}$ & $257.3 \mathrm{Bb}$ \\
\hline & 4 & $151.9 \mathrm{Aa}$ & $102.2 \mathrm{Aa}$ & $181.1 \mathrm{Aa}$ \\
\hline & CV (\%) & & 8.1 & \\
\hline \multirow{5}{*}{ SL (cm.seedling ${ }^{-1}$ ) } & 1 & $9.5 \mathrm{Aa}$ & $9.5 \mathrm{Aba}$ & $10.1 \mathrm{Aa}$ \\
\hline & 2 & $5.9 \mathrm{Bc}$ & $9.3 \mathrm{ABa}$ & $7.3 \mathrm{BCb}$ \\
\hline & 3 & $6.9 \mathrm{Bb}$ & $8.2 \mathrm{Bab}$ & $7.1 \mathrm{Cb}$ \\
\hline & 4 & $9.0 \mathrm{Ab}$ & $10.4 \mathrm{Aa}$ & $9.2 \mathrm{ABb}$ \\
\hline & CV (\%) & & 11.6 & \\
\hline \multirow{5}{*}{ SE (\%) } & 1 & $36 \mathrm{Bb}$ & $60 \mathrm{Ba}$ & $27 \mathrm{Bc}$ \\
\hline & 2 & $25 \mathrm{Cb}$ & $43 \mathrm{Ca}$ & $34 \mathrm{Bab}$ \\
\hline & 3 & $26 \mathrm{Bb}$ & $37 \mathrm{Ca}$ & $21 \mathrm{Cb}$ \\
\hline & 4 & $54 \mathrm{Ab}$ & $75 \mathrm{Aa}$ & $38 \mathrm{Ac}$ \\
\hline & CV (\%) & & 15.5 & \\
\hline
\end{tabular}

*Capital letters: comparisons in each column; small letters: comparisons in each row (Tukey test, $\mathrm{p} \leq 0.05$ ).

Table 5. Germination (G), accelerated aging (AA), electrical conductivity (EC), seedling length (SL), seedling emergence (SE) and water content of four lots of 'Itapuã 600 ' pea seeds, at the beginning of storage.

\begin{tabular}{cccccrr}
\hline Lots & G $(\%)$ & AA $(\%)$ & $\begin{array}{c}\text { EC } \\
\left(\mu \mathrm{mho.cm}^{-1} \cdot \mathrm{g}^{-1}\right)\end{array}$ & $\begin{array}{c}\text { SL } \\
\left(\mathrm{cm} . \text { seedling }^{-1}\right)\end{array}$ & SE $(\%)$ & Water content $(\%)$ \\
\hline 5 & $96 \mathrm{a} *$ & $69 \mathrm{a}$ & $65.5 \mathrm{a}$ & $10.3 \mathrm{a}$ & $89 \mathrm{a}$ & 9.0 \\
6 & $89 \mathrm{ab}$ & $36 \mathrm{~b}$ & $82.0 \mathrm{~b}$ & $8.0 \mathrm{~b}$ & $72 \mathrm{~b}$ & 9.4 \\
7 & $72 \mathrm{~b}$ & $15 \mathrm{c}$ & $113.1 \mathrm{c}$ & $5.5 \mathrm{c}$ & $52 \mathrm{c}$ & 9.2 \\
8 & $98 \mathrm{a}$ & $78 \mathrm{a}$ & $87.5 \mathrm{~b}$ & $11.3 \mathrm{a}$ & 8.6 & - \\
\hline $\mathrm{CV}(\%)$ & 11.1 & 12.8 & 10.1 & 7.7 & 9.8 \\
\hline
\end{tabular}

*Small letters: comparisons in each column (Tukey test, $\mathrm{p} \leq 0.05$ ).

Therefore, the results here obtained showed that the storage conditions were enough to maintain the differentiation of seed water content of the three cultivars at three levels: $8.0 \%$ to $9.1 \%$ in the dry chamber, $11.0 \%$ to $12.5 \%$ for the controlled environment and $12.0 \%$ to $14.1 \%$ for seeds kept in the laboratory, as planned initially; from the procedures adopted here it was possible to detect how these conditions could influence the intensity and speed of deterioration of the two cultivar seed lots. Vertucci et al (1994) found that the rate of deterioration increased when pea seeds were stored in an environment with more than $50 \%$ relative humidity.

Caliari and Marcos-Filho (1990) observed a very significant decrease in the germination and vigor of pea seeds with a high initial physiological potential, after eight months of storage, even for smooth seed cultivars, demonstrating the sensitivity of pea seeds to deterioration. In the present study, it was found that the wrinkled seeds really need to be stored at a relative humidity which can reduce metabolic activity 
to a minimum, because even the conservation of seeds with $8-9 \%$ water content may not be sufficient, except for lots of high initial physiological potential. A careful observation of the climate conditions during maturation and the pre-harvest phase is fundamental for reducing the probability of a high incidence of Aspergillus.

Table 6. Germination (G), accelerated aging (AA), electrical conductivity (EC), seedling length (SL), seedling emergence (SE) of four lots of 'Itapuã 600' pea seeds, after four months of storage in the laboratory (Lab), dry chamber and controlled environment (Controlled).

\begin{tabular}{|c|c|c|c|c|}
\hline \multirow{2}{*}{ Tests } & \multirow{2}{*}{ Lots } & \multicolumn{3}{|c|}{ Environments } \\
\hline & & $\mathrm{Lab}$ & Dry & Controlled \\
\hline \multirow{5}{*}{ G (\%) } & 5 & $85 \mathrm{Aa}^{*}$ & $87 \mathrm{Aa}$ & $89 \mathrm{Aa}$ \\
\hline & 6 & $76 \mathrm{Bb}$ & $81 \mathrm{Ba}$ & $70 \mathrm{Bb}$ \\
\hline & 7 & $40 \mathrm{Cb}$ & $53 \mathrm{Ca}$ & $56 \mathrm{Ca}$ \\
\hline & 8 & $92 \mathrm{Aa}$ & $96 \mathrm{Aa}$ & $91 \mathrm{Aa}$ \\
\hline & CV (\%) & & 7.5 & \\
\hline \multirow{5}{*}{$\mathrm{AA}(\%)$} & 5 & $50 \mathrm{Bb}$ & $66 \mathrm{Ba}$ & $48 \mathrm{Bb}$ \\
\hline & 6 & $11 \mathrm{Cb}$ & $29 \mathrm{Ca}$ & $09 \mathrm{Cb}$ \\
\hline & 7 & $03 \mathrm{Da}$ & $04 \mathrm{Da}$ & $11 \mathrm{Ca}$ \\
\hline & 8 & $64 \mathrm{Ab}$ & $85 \mathrm{Aa}$ & $77 \mathrm{Aa}$ \\
\hline & CV (\%) & & 11.4 & \\
\hline \multirow{5}{*}{$\begin{array}{c}\text { EC } \\
\left(\mu \text { mho.cm- }^{-1} \cdot \mathrm{g}^{-1}\right)\end{array}$} & 5 & $88.6 \mathrm{Aa}$ & $95.4 \mathrm{ABa}$ & $117.5 \mathrm{Ab}$ \\
\hline & 6 & $136.9 \mathrm{BCa}$ & $119.7 \mathrm{Ba}$ & $268.7 \mathrm{Cb}$ \\
\hline & 7 & $188.0 \mathrm{Ca}$ & $164.6 \mathrm{Ca}$ & $159.6 \mathrm{Ba}$ \\
\hline & 8 & $72.1 \mathrm{Aa}$ & $69.5 \mathrm{Aa}$ & $68.4 \mathrm{Aa}$ \\
\hline & CV (\%) & & 21.8 & \\
\hline \multirow{5}{*}{ SL (cm.seedling $\left.{ }^{-1}\right)$} & 5 & $10.6 \mathrm{Aa}$ & $11.0 \mathrm{Aa}$ & $10.6 \mathrm{Aa}$ \\
\hline & 6 & $8.0 \mathrm{Ba}$ & $8.4 \mathrm{Ba}$ & $8.0 \mathrm{Ba}$ \\
\hline & 7 & $4.7 \mathrm{Ca}$ & $5.6 \mathrm{Ca}$ & $4.7 \mathrm{Ca}$ \\
\hline & 8 & $11.8 \mathrm{Aa}$ & $11.0 \mathrm{Aa}$ & $11.8 \mathrm{Aa}$ \\
\hline & CV (\%) & & 11.7 & \\
\hline \multirow{5}{*}{ SE (\%) } & 5 & $79 \mathrm{Aa}$ & $80 \mathrm{Aa}$ & $78 \mathrm{Ba}$ \\
\hline & 6 & $59 \mathrm{Bb}$ & $66 \mathrm{Ba}$ & $46 \mathrm{Cb}$ \\
\hline & 7 & $32 \mathrm{Cb}$ & $43 \mathrm{Ca}$ & $44 \mathrm{Ca}$ \\
\hline & 8 & $83 \mathrm{Aa}$ & $86 \mathrm{Aa}$ & $91 \mathrm{Aa}$ \\
\hline & CV (\%) & & 8.1 & \\
\hline
\end{tabular}

*Capital letters: comparisons in each column; small letters: comparisons in each row (Tukey test, $\mathrm{p}<0.05$ ).

The information obtained here on seed performance during storage was based on the efficiency of tests used for the evaluation of physiological potential. Thus, the accelerated aging test at $41{ }^{\circ} \mathrm{C} / 48 \mathrm{~h}$, identified lots of higher vigor, but the effects of this combination temperature/period were very severe, thus confirming previous observations from Caliari and Marcos-Filho (1990), Hampton et al. (2004) and Nascimento et al. (2007).

The water contents of the aged seeds were between $26.6 \%$ and $28.5 \%$ under laboratory conditions, from $25.2 \%$ to $29.2 \%$ in a dry chamber and from $26.1 \%$ to $28.8 \%$ in the controlled environment, considering all the periods, lots and cultivars analyzed. Within each period and environment, these variations between samples were considered reasonable, confirming the adequacy of the test conditions.

The electrical conductivity test was also sensitive to differences between lots and storage conditions for both crops but differences for the 'Telefone Alta' lots were clearer. This association of the results from the electrical conductivity test to the pea cultivar was described by Bustamante et al. (1984), Caliari and Marcos-Filho (1990). In addition, Powell et al. (1997) working with peas, considered that although individual tests could identify differences in vigor, the influence of various factors related to the history of the seed lots meant that using only one test is usually insufficient for evaluating seed physiological potential. Therefore, a combination of procedures to identify the different attributes of seed vigor, and also considering the influence of the genotype, is necessary.

The importance of this may also be illustrated by the results from the seedling length test, which accurately identified differences among lots of the Telefone Alta cultivar, only after eight months of storage, but was sensitive to the differences between the 'Itapuã 600 ' lots during the whole storage period. 
Table 7. Germination (G), accelerated aging (AA), electrical conductivity (EC), seedling length (SL), seedling emergence (SE) of four lots of 'Itapuã 600' pea seeds, after eight months of storage in the laboratory (Lab), dry chamber and controlled environments (Controlled).

\begin{tabular}{|c|c|c|c|c|}
\hline \multirow{2}{*}{ Tests } & \multirow{2}{*}{ Lots } & \multicolumn{3}{|c|}{ Treatments } \\
\hline & & $\mathrm{Lab}$ & Dry & Controlled \\
\hline \multirow{5}{*}{$\mathrm{G}(\%)$} & 5 & $86 \mathrm{Aa}^{*}$ & $84 \mathrm{Aa}$ & $88 \mathrm{Aa}$ \\
\hline & 6 & $70 \mathrm{Ba}$ & $79 \mathrm{Aa}$ & $55 \mathrm{Bb}$ \\
\hline & 7 & $39 \mathrm{Cb}$ & $57 \mathrm{Ba}$ & $31 \mathrm{Cb}$ \\
\hline & 8 & $91 \mathrm{Aa}$ & $93 \mathrm{Aa}$ & $93 \mathrm{Aa}$ \\
\hline & CV (\%) & & 10.4 & \\
\hline \multirow{5}{*}{ AA (\%) } & 5 & $20 \mathrm{Bb}$ & $52 \mathrm{Ba}$ & $27 \mathrm{Ab}$ \\
\hline & 6 & $01 \mathrm{Cb}$ & $10 \mathrm{Bab}$ & $01 \mathrm{Bb}$ \\
\hline & 7 & $01 \mathrm{Cb}$ & $02 \mathrm{Ca}$ & $01 \mathrm{Ba}$ \\
\hline & 8 & $47 \mathrm{Ab}$ & $77 \mathrm{Aa}$ & $24 \mathrm{Ac}$ \\
\hline & CV (\%) & & 22.4 & \\
\hline \multirow{5}{*}{$\begin{array}{c}\text { EC } \\
\left(\mu \mathrm{mho} \cdot \mathrm{cm}^{-1} \cdot \mathrm{g}^{-1}\right)\end{array}$} & 5 & $115.1 \mathrm{Ba}$ & $116.7 \mathrm{Ba}$ & $133.5 \mathrm{Ba}$ \\
\hline & 6 & 138.3 Bab & $131.0 \mathrm{Ba}$ & $162.3 \mathrm{Cb}$ \\
\hline & 7 & $187.6 \mathrm{Ca}$ & $183.2 \mathrm{Ca}$ & $207.9 \mathrm{Da}$ \\
\hline & 8 & $70.4 \mathrm{Aa}$ & 81.2 Aa & 77.2 Aa \\
\hline & CV (\%) & & 10.3 & \\
\hline \multirow{5}{*}{$\mathrm{SL}\left(\mathrm{cm}\right.$. seedling $\left.{ }^{-1}\right)$} & 5 & $9.3 \mathrm{Ab}$ & $11.5 \mathrm{Aa}$ & $9.7 \mathrm{Ab}$ \\
\hline & 6 & $7.5 \mathrm{Bb}$ & $8.5 \mathrm{Ba}$ & $6.2 \mathrm{Bc}$ \\
\hline & 7 & $4.7 \mathrm{Cbc}$ & $5.5 \mathrm{Ca}$ & $3.9 \mathrm{Cc}$ \\
\hline & 8 & $10.2 \mathrm{Aa}$ & $10.7 \mathrm{Aa}$ & $10.2 \mathrm{Aa}$ \\
\hline & CV (\%) & & 8.3 & \\
\hline \multirow{5}{*}{ SE $(\%)$} & 5 & $59 \mathrm{Bb}$ & $80 \mathrm{Aa}$ & $66 \mathrm{Bb}$ \\
\hline & 6 & $37 \mathrm{Cb}$ & $58 \mathrm{Ba}$ & $24 \mathrm{Cc}$ \\
\hline & 7 & $17 \mathrm{Db}$ & $28 \mathrm{Ca}$ & $19 \mathrm{Cb}$ \\
\hline & 8 & $85 \mathrm{Aa}$ & $89 \mathrm{Aa}$ & $87 \mathrm{Aa}$ \\
\hline & CV (\%) & & 9.3 & \\
\hline
\end{tabular}

*Capital letters: comparisons in each column; small letters: comparisons in each row (Tukey test, $\mathrm{p}<0.05$ ).

This study increased our knowledge of wrinkled pea seed behavior during storage and identified tests for determining the vigor of stored seeds. These observations are important to improve our knowledge about pea seed storage since research on pea seed physiological potential has been concentrated on the relationship between vigor and seedling emergence in the field and not their performance during storage.

\section{Conclusions}

The initial physiological potential is fundamental for conserving germination and vigor of pea seeds during storage.

Wrinkled pea seeds should be stored between harvest and sowing in an environment in which the sum of the relative humidity $(\%)$ and temperature $\left({ }^{\circ} \mathrm{C}\right)$ is less than 70 .

The evaluation of the physiological potential of pea seeds should be performed by at least two vigor tests and the inclusion of the accelerated aging and electrical conductivity tests is recommended.

\section{Acknowledgements}

To the CNPq (Council for Scientific and Technological Development) for granting scholarships and providing resources for this study.

\section{References}

ABDALLA, F.H.; ROBERTS, E.H. The effect of seed storage conditions on the growth and yield of barley, broad beans and peas. Annals of Botany, v.33, p.169-184, 1969.

BAUDET, L. Armazenamento de sementes. In: PESKE, S.T.; ROSENTHAL, M.D.; ROTA, G.R.M. Sementes: fundamentos científicos e tecnológicos. Pelotas: UFPel Editora e Gráfica Universitária, 2003. p.366-415.

BRADNOCK, W.T.; MATTHEWS, S. Assessing field emergence /potential of wrinkled-seeded peas. Horticultural Research, v.10, p.50-58, 1970.

BRASIL. Ministério da Agricultura, Pecuária e Abastecimento. Regras para análise de sementes. Ministério da Agricultura, Pecuária e Abastecimento. Secretaria de Defesa Agropecuária. Brasília, DF: MAPA/ACS, 2009. 395p. http://www.agricultura.gov.br/arq_editor/file/laborat\%c3\%b3rio/sementes/ regras $\% 20$ para $\% 20$ analise $\% 20 \mathrm{de} \% 20$ sementes.pdf 
BUSTAMANTE, L.; SEDDON, M.G.; DON. R; RENNIE, W.J. Pea seed quality and seedling emergence in the field. Seed Science and Technology, v.12, p.551-558, 1984.

CALIARI, M.F.; MARCOS-FILHO, J. Comparação entre métodos para avaliação da qualidade fisiológica de sementes de ervilha. Revista Brasileira de Sementes, v.12, p.52-73, 1990.

CARVALHO, N.M.; NAKAGAWA, J. Sementes: ciência, tecnologia e produção. 4. ed. Jaboticabal: FUNEP, 2000. 588 p.

CHRISTENSEN, C.M. Microflora and seed deterioration. In: Roberts, E.H. Viability of seeds. Syracuse University Press, 1972, p. 59-93.

DELOUCHE, J.D.; MATTHES, R.K.; DOUGHERTY, G.M.; BOYD, A.H. Storage seed in subtropical and tropical regions. Seed Science and Technology, v.21, p.671-700, 1973.

DOIJODE, S.D. Seed storage of horticultural crops. New York: Food Products Press, 2001. 339 p.

GIORDANO, L.B. Brasília, Cultivo da ervilha. EMBRAPA/CNPH, 1997. 19 p. Instruções Técnicas.

HAMPTON, J.G; BRUNTON, B.J.; PEMBERTON, G.M.; ROWARTH, J.S. Temperature and time variables for accelerated ageing vigour testing of pea seed. Seed Science and Technology, v. 32, p. 261-264, 2004.

LUCCA FILHO, O.A. Metodologia dos testes de sanidade de sementes. In: SOAVE, J.; WETZEL, M.M.V.S. (Ed.). Patologia de sementes. Campinas: Fundação Cargill, 1987. p. 430-440.

MENEZES, J.E., NASCIMENTO, W.M. Teste de envelhecimento precoce em sementes de ervilha. Horticultura Brasileira, v. 63 (suplemento).

NAKAGAWA, J. Testes de vigor baseados no desempenho das plântulas. In: KRZYZANOWSKI, F.C.; VIEIRA, R.D.; FRANÇA-NETO, J.B. Vigor de sementes: conceitos e testes. Londrina: ABRATES, 1999. p. 2.1-2.24.
NASCIMENTO, W.M.; CICERO, S.M. Qualidade de sementes de ervilha tratadas com fungicidas. I. Qualidade sanitária. Revista Brasileira de Sementes, v.13, p.5-12, 1991a.

NASCIMENTO, W.M.; CICERO, S.M. Qualidade de sementes de ervilha tratadas com fungicidas. I. Qualidade fisiológica. Revista Brasileira de Sementes, v.13, p.13-19, 1991b.

NASCIMENTO, W.M.; FREITAS, R.A.; GOMES, E.M.L.; SOARES, A.S. Metodologia para o teste de envelhecimento acelerado em sementes de ervilha. Horticultura Brasileira, v. 25, p.205-209, 2007. http://www.scielo. $\mathrm{br} / \mathrm{scielo}$.php?script=sci_abstract\&pid=s0102-05362007000200015\&lng=en $\&$ nrm $=$ iso\&tlng $=$ pt

POWELL, A.A.; FERGUSON, A.J.; MATTHEWS, S. Identification of vigour differences among combining pea seed lots. Seed Science and Technology, v.25, p.443-464, 1997.

SIDDIQUE, A. B.; WRIGHT, D. Effects of date of sowing on seed yield and seed germination and vigor of peas and flax. Seed Science and Technology, v. 32, p.455-572, 2004.

SUN, W.Q. Methods for the study of water relations under desiccation stress. Black, M.; Pritchard, H.W. (ed.). Desiccation and survival in plants: drying without dying. Wallingford, CABI Publishing, 2002. p.48-83.

VERTUCCI, C.A.; ROOS, E.E.; CRANE, J. Theoretical basis of protocols for seed storage III. Optimum moisture contents for pea seeds stored at different temperatures. Annals of Botany, v.74, p.531-540, 1994.

VIEIRA, R.D.; KRZYZANOWSKI, F.C. Teste de condutividade elétrica. In: KRZYZANOWSKI, F.C.; VIEIRA, R.D.; FRANÇA-NETO, J.B. (Ed.). Vigor de sementes: conceitos e testes. Londrina: Abrates, 1999. p.1-26. 